\title{
PRIVATE BUILDINGS AND THEIR JURIDICAL CONTEXT IN THE BYZANTINE NEAR EAST
}

EDIFICI PRIVATI E LORO CONTESTO GIURIDICO NEL VICINO ORIENTE BIZANTINO

Aneta Skalec*

\begin{abstract}
:
Private buildings were the object of regulations already in the Law of XII Tablets, and in polis in classical Greece but it is only from the Byzantine period that we have preserved more detailed regulations, both in the imperial constitutions and in local laws from the Near East - Liber Syro-Romanus and, above all, in Julian of Ascalon's Treatise. The last one is the longest and the most complex collection of rules concentrated exclusively on private buildings and their parts characteristic of the Near Eastern constructions - a courtyard, a flat roof used for many domestic activities, balconies, windows etc. We find there a very detailed description of the regulations concerning construction, renovation and maintenance of the houses and their appurtenances. Thanks to all of these sources we receive an exhaustive picture of the Near East domestic architecture of the Byzantine period in its juridical context.
\end{abstract}

Keywords: Private buildings. Roman law. Julian of Ascalon's Treaties. Near East. Constitution of Zeno.

Riassunto:

Gli edifici privati sono stati oggetto di regolamenti già nelle XII Tavole e nelle polis greche, ma solo dal periodo bizantino sono pervenute a noi le regolamentazioni più dettagliate su questo tema sia nelle costituzioni imperiali sia nelle fonti locali dal Vicino Oriente - Liber Syro-Romanus ed in particolare nel Trattato di Giuliano d'Ascalone. Quest'ultimo è la più lunga e complessa collezione di regole concentrate solo esclusivamente sul tema degli edifici privati e loro giardini, caratteristici nelle costruzioni del Vicino Oriente - il cortile, il tetto piatto utilizzato per tante attività domestiche, balconi, finestre etc. Troviamo molto dettagliate regolamentazioni, riguardanti la costruzione, ristrutturazione e mantenimento delle case. Grazie a tutte queste fonti otteniamo un'ampio panorama dell'architettura domestica nel Vicino Oriente nel periodo bizantino, nel suo contesto giuridico.

Parole chiavi: Edifici privati. Diritto romano. Trattato di Giuliano d'Ascalone. Vicino Oriente. Costituzione di Zeno.

We find the first private buildings regulations in the Law of the XII Tablets ${ }^{1}$ and in the classical Greece (Stela from Thasos - 5th cen. BC ${ }^{2}$ and text from Pireus - 4th cen.

$\mathrm{Ph} . \mathrm{D}$. in progress at the University of Warsaw.

1 Tab. 7.1 Obligation to leave a free space of 2, 5 feet around a house; Tab. 10, 9 prohibiting construcion of a funeral pile in the distance of 60 feets from the neighbour building.

2 DUCHENE Herve. La Stèle du Port. Fouilles du Port 1. Recherches sur une nouvelle inscription thasienne. Athens 1992. 
BC) and later on in the Hellenistic (Pergamon - the Law of The Astynomoi of Pergamon; ${ }^{3}$ Egypt - the so called legal code from Hermopolis ${ }^{4}$ from 3 th cen. BC and Dikaiomata ${ }^{5}$ from the same century) and Roman period, ${ }^{6}$ but this kind of laws, as usually being compilations of norms concerning many different meters, was only in small part related to private dwellings. Also normally they were concentrated only on particular problems related to the question, like the safety of the buildings with a special reference to the risk of fire or protection of walls, the distance between buildings or their height. Generally, the laws that survived till our times did not concern the technical aspects of the dwellings or particular parts of them. It is only from the Byzantine period that we have preserved more detailed regulations, both in the imperial constitutions (in the fifth and sixth centuries, the central administration shows an increasing interest in private construction ${ }^{7}$ ) and in local laws from the Near East, which gave as a greater possibility to confront the legal reality with the material testimonies.

As we know, thanks to the archaeological surveys and excavations, private buildings in the Byzantine Near East were characterized generally by the same features as houses in earlier periods in this territory and often the structures from Roman period were continuously used also during the Byzantine times.

The most tipical element of the private buildings in ancient Near East was a courtyard, which was an integral part of the house, serving as a space of daily activities such as cooking, baking, eating and also as place for various installations for keeping animals and storing their fodder ${ }^{8}$. Because of its character and position Yizhard Hirschfeld ${ }^{9}$ proposed a basic division of private dwellings in three main types:

-the simple house - a house built at one side of the courtyard;

-the complex house - a house consisting of dwelling units and various wings arranged around part of the courtyard;

\footnotetext{
AMELOTTI Mario. L'epigrafe di Pergamo sugli astynomoi e il problema della recezione di leggi straniere nell'ordinamento giuridico romano. In: Studia et Documenta Historiae et Iuris 24 (1958), p. 81-2.

4 MATTHA Girgis. The demotic legal code of Hermopolis West. Kairo 1975. Greek version of this demotic text is known from 2th cen. AD and published by John Rea in P. Oxy. 3285.

5 P. Hal. 1. 11. 80-105. Dikaiomata: Auszüge aus alexandrinischen Gesetzen und Verordnungen in einem Papyrus des Philologischen Seminars der Universität Halle (Pap. Hal. 1) mit einem Anhang weiterer Papyri derselben Sammlung, Berlin 1913, p. 69. Translation in english: BAGNALL Roger S., DEROW Peter. The Hellenistic Period: Historical Sources in Translation. Malden 2004, p. 206-210.

6 STRABO 5. 3. 7, TACITUS. Ann. XV, 43, D. 8,2,14; Senatusconsultum Hosidianum (44 AD), Senatusconsultum Volusianum (56 AD); Senatusconsultum Acilianum (212AD), constitutions of imperators mentioned in the Codex Justinianus -Justinian's Code (C.8.10.12 -Vespasian, C. 8.10.1 - Traian)

7 SALIOU Catherine. The Byzantine House (400-912): Rules and Representations. In: GRÜNBART Michael, KISLINGER Ewald, MUTHESIUS Anna, STATHAKOPOULOS Dionysios Ch. (ed.). Material Culture and Well-Being in Byzantium (400-1453), Wien 2007, p. 200.

8 HIRSCHFELD Yizhar. The Palestinian Dwelling in the Roman- Byzantine Period. Jerusalem 1995, p. 289.

9 HIRSCHFELD Yizhar. Op. cit. p. 21-22, 272-73.
} 
-the courtyard house - a house built around an enclosed inner courtyard.

1. The Simple House - is the most basic and commonly found type, consisting of a one- or more roomed structure built either behind or in front of an open courtyard. Usually their had one or two storeys, but their might be, in spite of the name, of big sizes and of very good quality. A good example of this type can be found at Horvat Susiya (southeast of Hebron, 6-8th cent; one story, with a courtyard on the east, fig. 1), Horvat Kanaf (Galilea, 5-6th. cent., fig. 2) or Horvat Shema (4-5th. cent., two-storied, fig. 3).

- The sub-type of the simple house is the two-wings house with two perpendicular wings, usually built in the northern part of the courtyard (ex. Nahal ha-Ro'a, 5-7th. cen., fig. 4).

- Another variant of this simple house is the tower-like house found usually in isolated areas - a narrow structured dwelling with at least two or tree stories with the courtyard almost always set alongside the house.

The Complex House - a house consisting of dwelling units and various wings arranged around part of the courtyard. This type is often an extension of the simple house through the addition of new wings or dwellings units built around three or more sides of the originally outer courtyard.

This type may be divided into two groups:

an urban apartment house, belonging to different families that shared the same courtyard, and as name shows being typical for urban spaces. This type was created by the construction of adjoining dwelling units around a common courtyard, examples of witch we can find at Um el-Jimal (Hauran, 2-3th cen., inhabited to the end of the Byzantine period.); Pella - large complex apartment house (7-8th) with two courtyards and three entrances from the street (fig. 5); Gerasa (7-8th) house composed of 5-6 separate dwellings units belonging to families that shered the same courtyard (fig. 6).

a rural farmhouse, tipical for rural settlement, was composed of several dwelling units and wings built around a central courtyard. Many farmhouse were gradually expanded from a simple-type structure to a more complex through the addition of new wings, storerooms around the central courtyard, the best example of which is the building A at Kafr Nassej (Hauran, fig. 7) - originally built in the Roman period as a simple-type house and later on enlarged through the addition of residential and services wings around the courtyard. 
The Courtyard House - a house built around an enclosed inner courtyard, surrounded on all four sides by the wings of the dwelling structure, giving in the urban areas (for which it is typical) the possibility of maximum utilization of urban space. It is distinguished from the complex-type house by clear architectural planning and, in contrast to it, it has not gradually developed from an original, small dwellings, but was constructed around an inner courtyard from the begining ${ }^{10}$.

This type may also be divided into two groups:

- a house with an inner courtyard without columns, which represents the continuity of an ancient local tradition. The examples of this type can be usually found in the city, e.g. the courtyard house of the Temple Mount in Jerusalem from 5-7th cen. (fig. 8) with the balcony opened to the courtyard; twin courtyard houses (A and B) at Khorazin (fig. 9) in the center of the city belonged to the wealthy landowners (57th); Pella (eastern side of Jordan River) - several courtyard houses from 4-5th cen. A few examples were discovered in the rural settlements, like Shivta - Pool house (fig. 10) form 5-7th cent. or Byzantine villa (6th-7th) at Ramat Handavi at the southern edge of Mount Carmel.

house with an inner courtyard with columns (also known as the atrium or peristyle house), which reflects the architectural traditions of the Greek-Roman culture. We find examples of them first of all in big, prosperous cities in Near East, with a visible influence of the Greek-Roman tradition, like Palmyra (house of Achilles and Casiopea 3 th $^{11}$ or building F (fig. 11) - 2-8th ${ }^{12}$, building 39, 38 or $45^{13}$ ), Antiochia, Apamea (la Maison aux aux Consoles ${ }^{14}$ ), Gerasa (maison dite ,de la mosquee omayyade" from the Late Antiquity, fig. 12) ${ }^{15}$ or Jerusalem ${ }^{16}$ (4-5th cen., fig. 13).

$10 \quad$ HIRSCHFELD Yizhar. Op. cit., p. 80.

11 BALTY Jean-Charles. La maison urbaine en Syrie. In: DENTZER Jean-Marie, ORTHMANN Winfried (eds.). Archeologie et historie de la Syrie II, La Syrie de l' époque achéménide à l'avènement de 1'Islam. Saarbrücker 1989. p. 410.

12 GAWLIKOWSKI Michał. Beyond the Colonnades: Domestic Architecture in Palmyra. In: GALOR Katharina, WALISZEWSKI Tomasz (eds.). From Antioch to Alexandria. Recent studies in domescti architecture. Warszawa 2007. p. 80-93.

13 FREZOULS Edmond. A propos de l'architecture domestique a Palmyre. In: Ktema 1 (1976), p. 29-52.

14 BALTY Janine, La Maison aux Consoles. In: BALTY Janine (eds.), Actes du colloque Apamée de Syrie. Bilan des recherches archéologiques 1973-1979. Bruxelles 1984, p. 19-24.

15 SEIGNE Jacques. Habitat hellenistique et romain de Gerasa. In: CASTEL Corinne, MAQDISI Mishal, VILLENEUVE Francois (eds.). Les maisons dans la Syrie antique du III millénaire aux débuts de l'islam. Actes du Colloque International, Damas 27-30 juin 1992. Beyrouth 1997, p. 76.

16 HIRSCHFELD Yizhar. Op. cit., p. 95-97. 

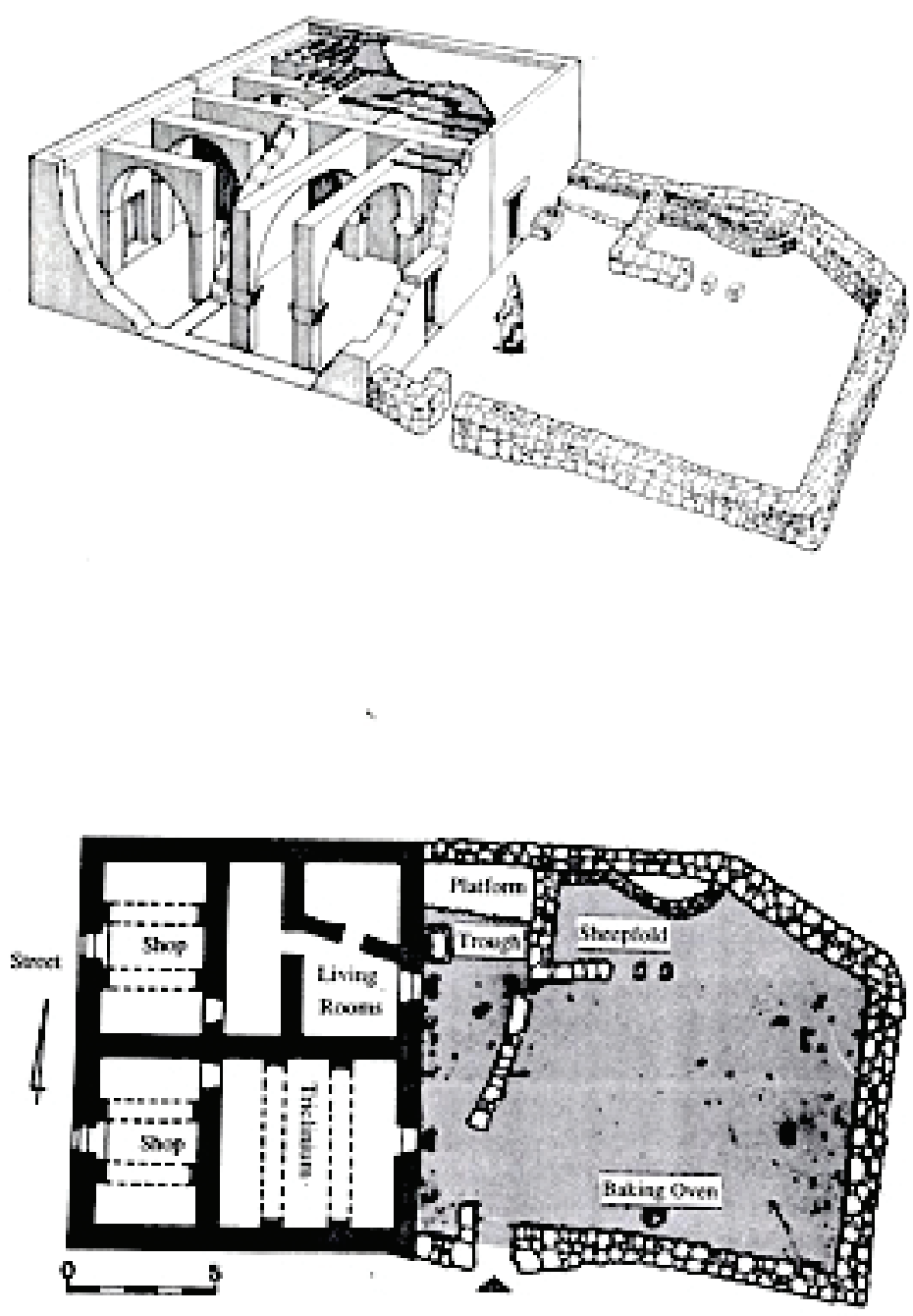

Fig. 1. Plan and reconstruction of a house at Horvat Susiya. 


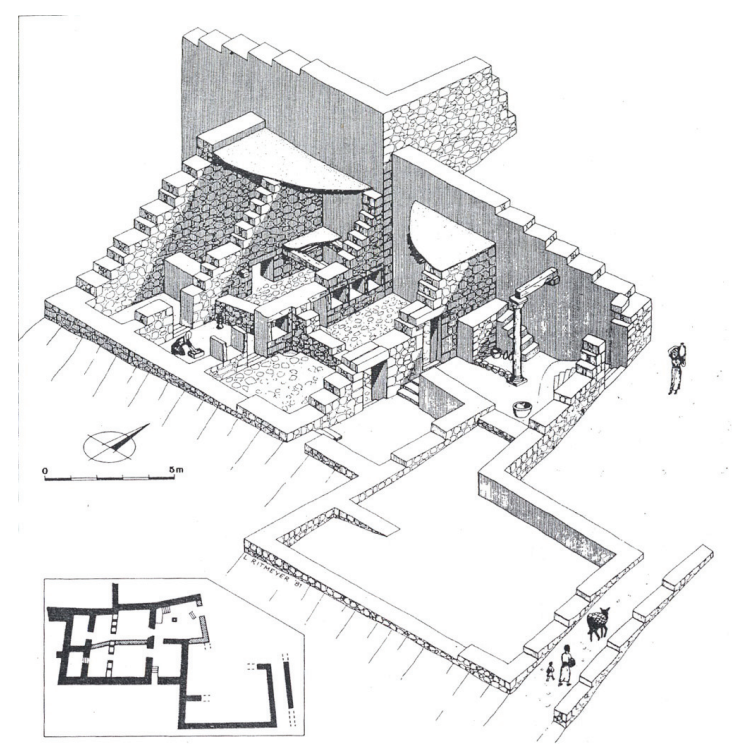

Fig. 2. Plan and reconstruction of a house at Horvat Kanaf.
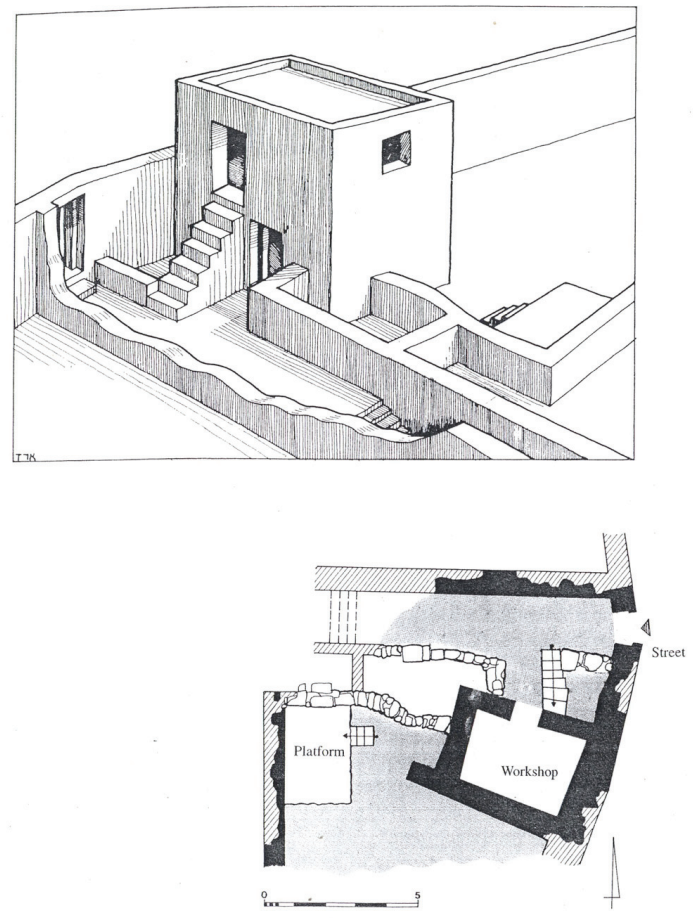

Fig. 3. Plan and reconstruction of a house at Horvat Shema. 


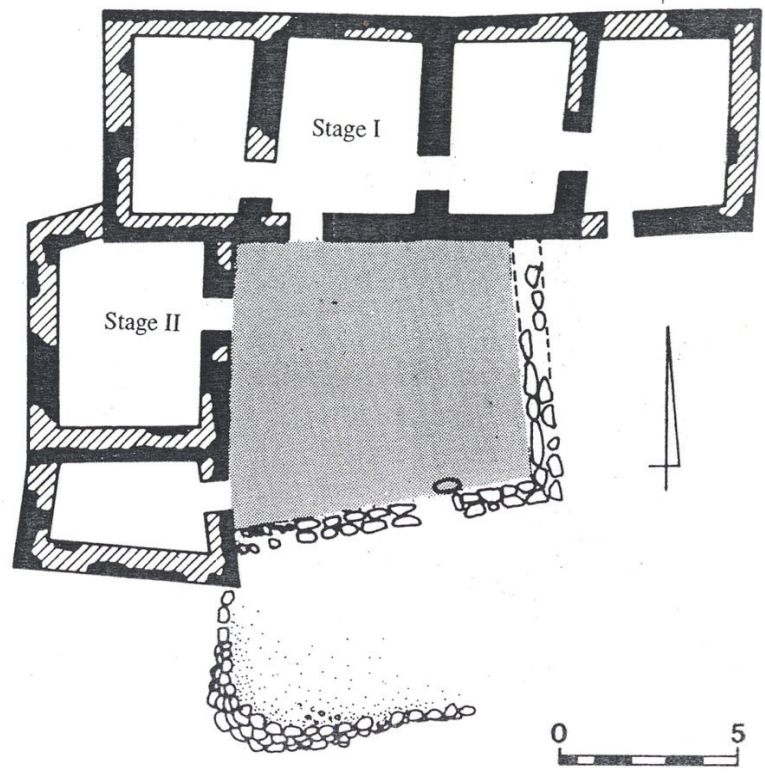

Fig. 4. Plan of two-winged house at Nahal ha-Ro'a.

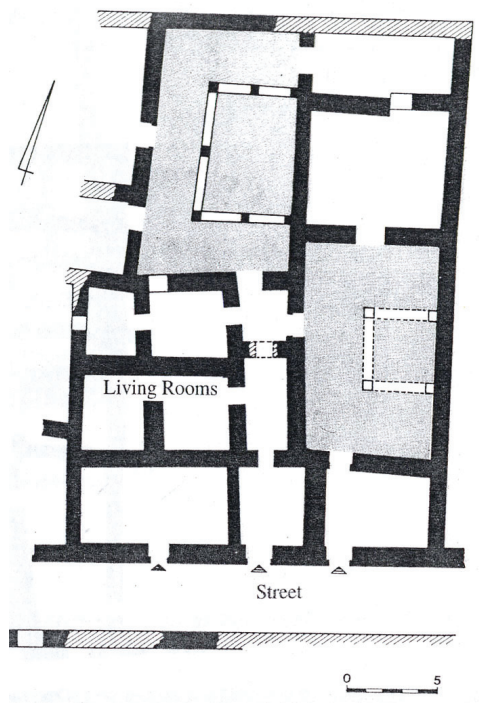

Fig. 5. Plan of an apartement house at Pella. 


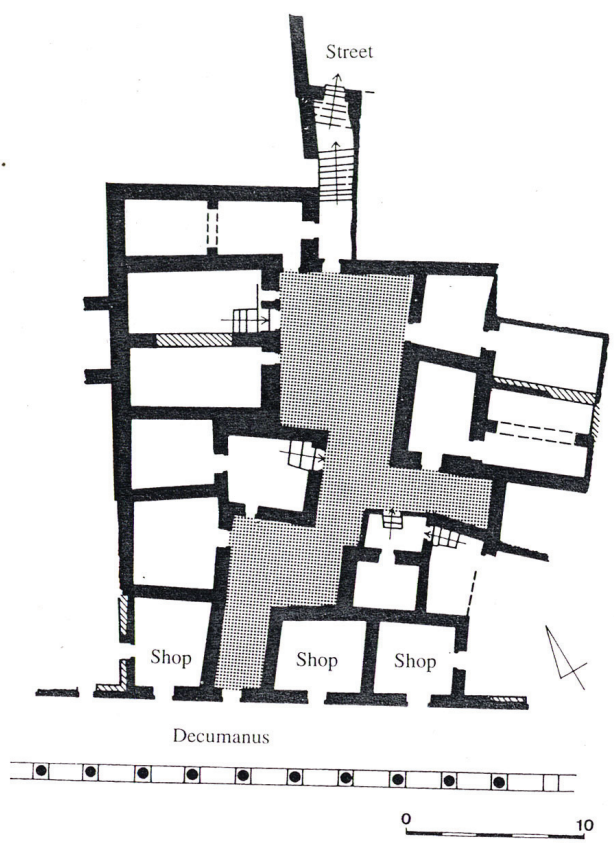

Fig. 6. Plan of an apartement house at Gerasa.

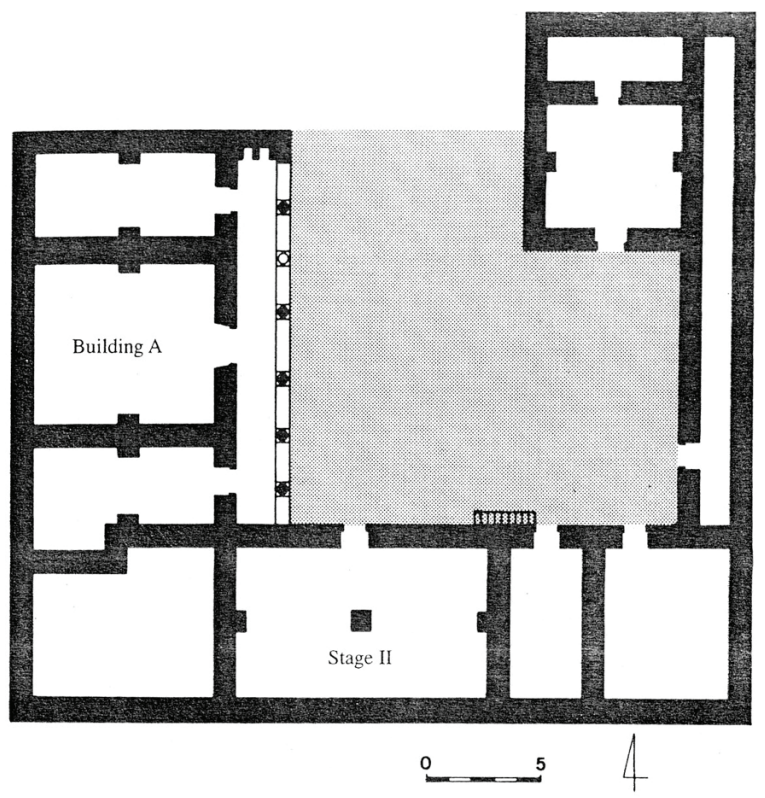

Fig. 7. Plan of Building A at Kafr Nassej. 


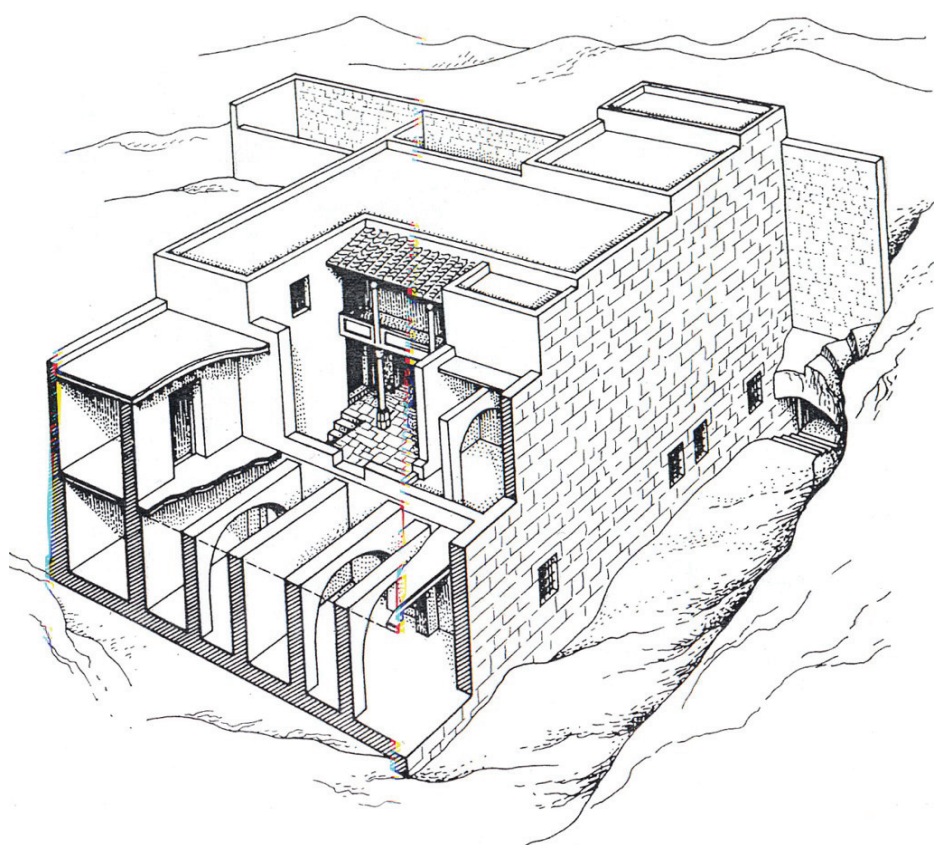

Fig. 8. Reconstruction of a courtyard house at Jerusalem.

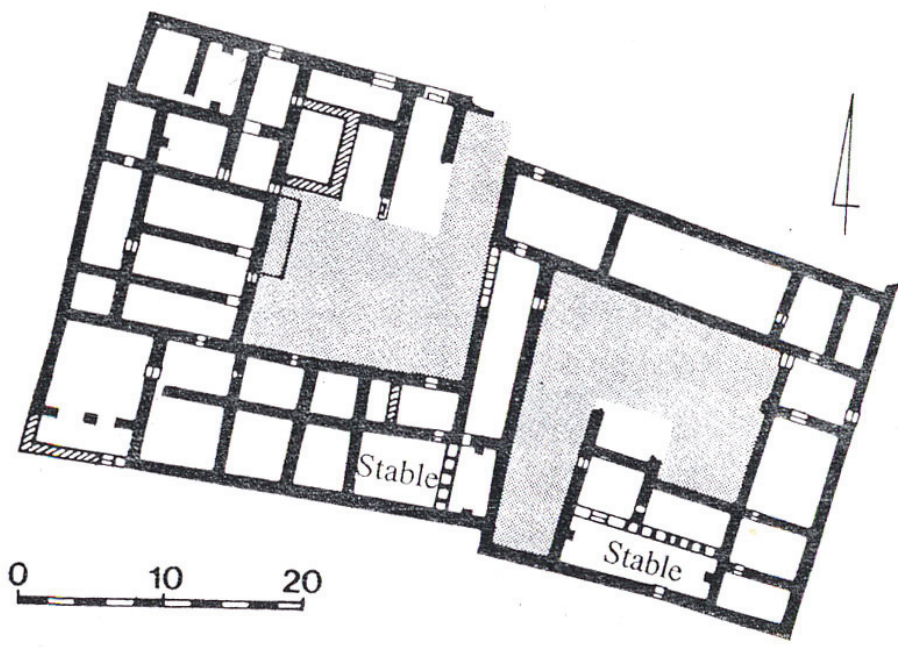

Fig. 9. Plan of the central courtyard houses at Khorazin. 


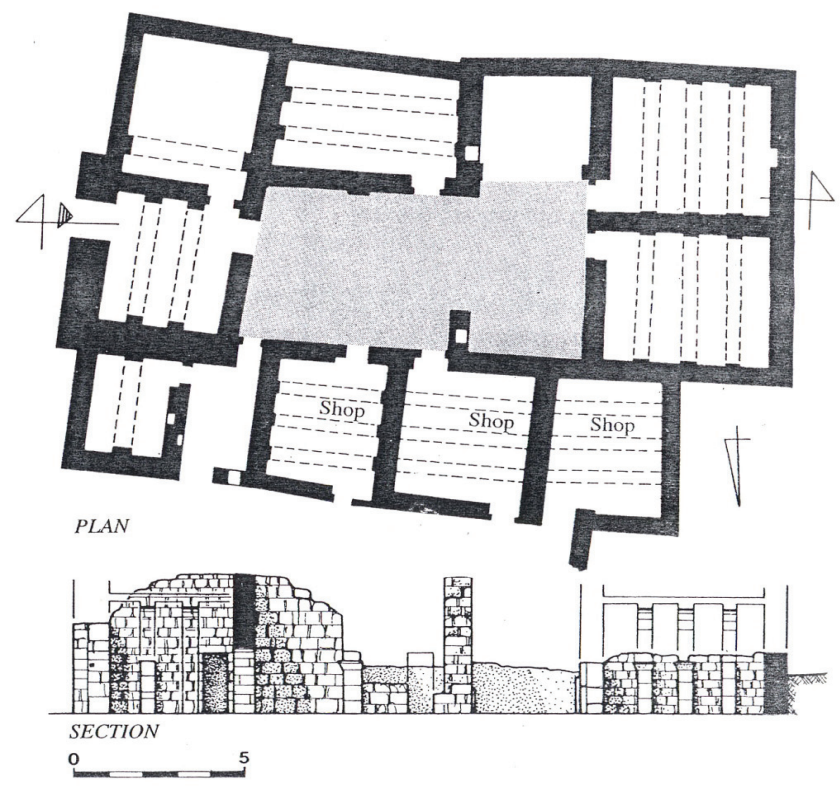

Fig. 10. Plan and section of the „Pool House” at Shivta.

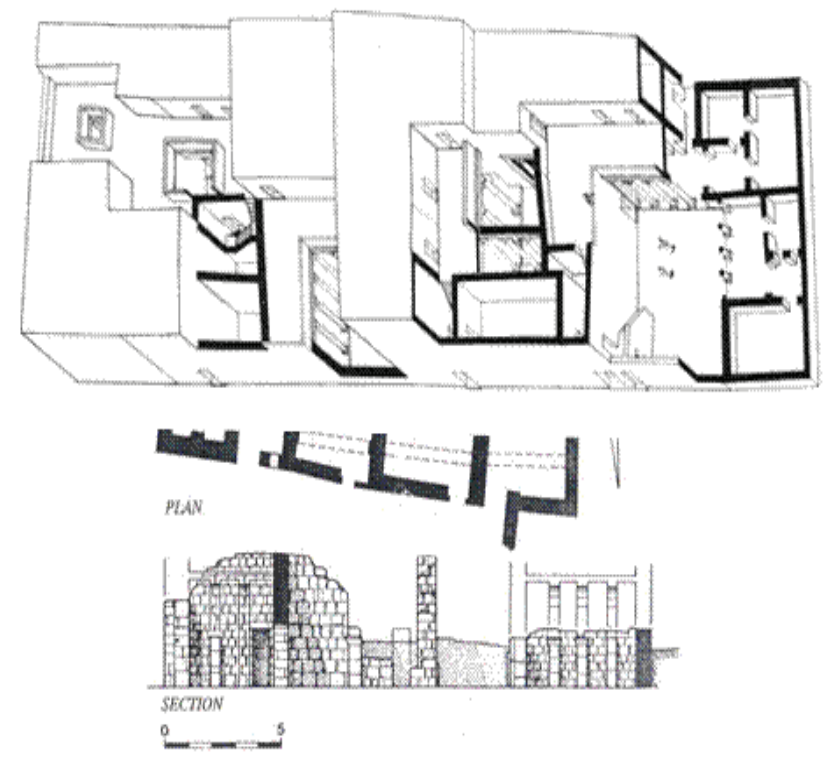

Fig. 11. Reconstruction of the building F at Palmyra. 


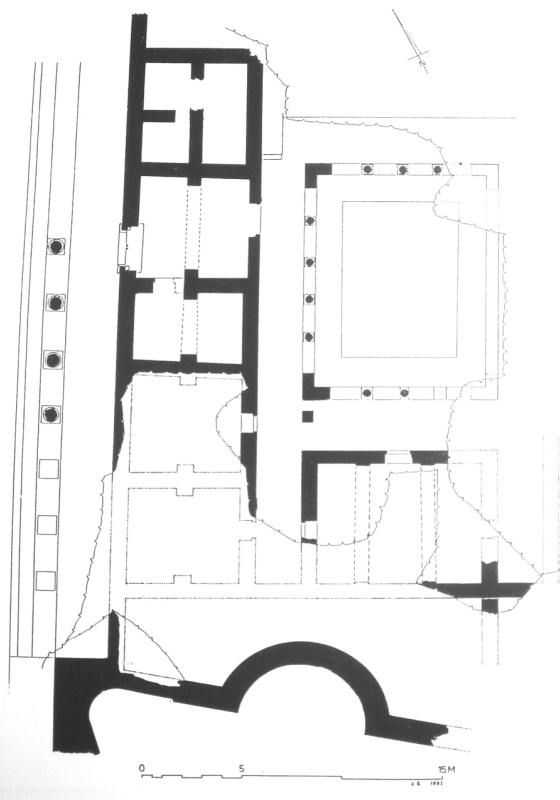

Fig. 12. Plan of the maison dite „de la mosquee omayyade” at Gerasa.
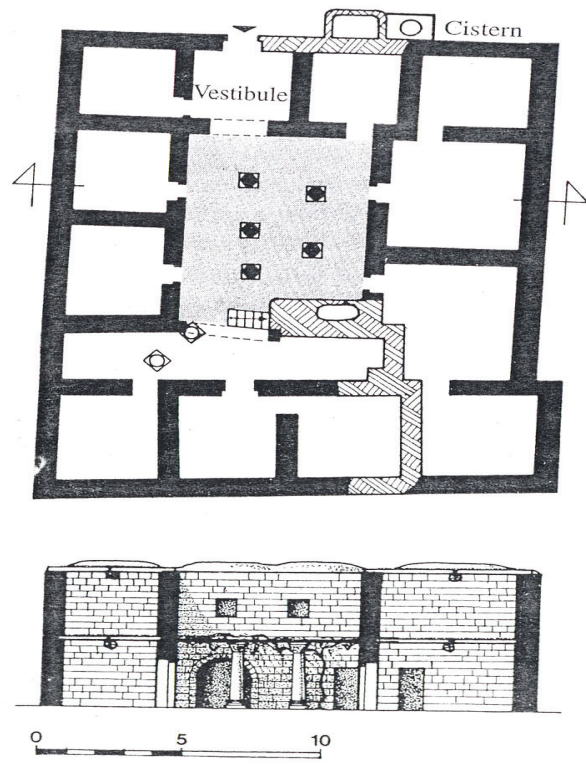

Fig. 13. Plan and reconstructed section of peristyle house at Jerusalem. 
Houses of the courtyard-type were generally typical for urban spaces and houses of the simple-type usually were characteristic for rural settelments, but in this period the distinction between urban and rural areas was not always clear, so we frequently find courtyard-type houses in small towns and even villages. In rural areas, buildings with inner courtyard were almost exclusively villas of wealthy families ${ }^{17}$. Generally we can find more examples of domestic architecture in village settelments then in cities, except Palmyra, Dura Europos and Apamea, where excavations have been conducted. ${ }^{18}$

Another characteristic feature of houses in the Byzantine Near East was the presence of usually flat roof surrounded by balustrades (with an exception of dwellings in limestone massif in northern Syria, which had tiled gabled roffs ${ }^{19}$ ), which was used for daily activities and can be seen as a direct extension of the courtyard area. ${ }^{20}$

The windows of houses were usually built in the upper parts of the walls and they tended to be few and small in size. ${ }^{21}$

As far as the number of stories is concerned, many dwellings were one or two-storied. In the latter case usually the lower story was used for service installations (including stables) and the upper story was used for living quarters. ${ }^{22}$ But the possibility of existence of higher dwellings in the Near East is confirmed by some archaeological remains (building number II at Mampsis) and also by literary sources. Libanios informs as about presence of three-storied dwellings in Antiochia ${ }^{23}$ and Jewish sources mentioned buildings in the cities which had three or even five levels. ${ }^{24}$

About which elements of Byzantine Near East houses do we have information from legal sources?

I will begin with the imperial constitutions. Still in the Codex Theodosianus from $438 \mathrm{AD}$ we do not find any specific chapter about private buildings and there are only same points about this in the sections concerning public works and water supply (C. Th. 15, 1-2), ${ }^{25}$ but with limitation to the problem of the distance between buildings. ${ }^{26}$ In

\footnotetext{
HIRSCHFELD Yizhar. Op. cit., p. 290.

BALTY Jean-Charles. Op. cit. p. 407.

TATE Georges. La maison rurale en Syrie du Nord. In: CASTEL Corinne, MAQDISI Mishal, VILLENEUVE Francois (eds.). Les maisons dans la Syrie antique du III millénaire aux débuts de l'islam. Actes du Colloque International, Damas 27-30 juin 1992. Beyrouth 1997, p. 96. More about this dwellings in this articles and also: TATE Georges. Asetto del villagio. In: La Civilta bizantina. Ogetti e messaggio. Architettura e ambiente di vita. Corso di studi 6, 1981, p. 75- 171. TCHALENKO GEORGES. Villages antiques de la Syrie du Nord. Le massif du Belus a l'epoque romaine. Paris 1953-58.

20 HIRSCHFELD Yizhar. Op. cit., p. 289.

21 HIRSCHFELD Yizhar. Op. cit., p. 289.

22 HIRSCHFELD Yizhar. Op. cit., p. 289.

23 LIBANIOS. Oratio 11. 225.

24 T. Eruvin 8:3; P. T. Baba Bathra 1, 13 a. After HIRSCHFELD Yizhar. Op. cit., p. 264.

25 SALIOU Catherine. The Byzantine House, p. 200.

26 C. Th. 15,1,4 Omnis intra centum pedes vicinitas, quantum ad horrea pertinent, arceatur ac, si quid constructum fuerit, diruatur, quoniam experimentis nuperrimis palam factum est aedificiorum quae horreis adhaerebant, incendiis fiscales copias laborasse.
} 
contrast, in the codex of Justinian (534) there is a specific title concerning private buildings (C. 8.10. De aedificiis privatis) consisting of 14 constitutions. The most important of them is the law of Zeno (C. 8.10.12) concerning urban constructions in Constantinopole, emanated between 476 and $479^{27}$ (which refers to the constitution of Leo enacted probably after the fire of Constantinopol in 462 and containing rules for the reconstruction of the city, which we know through an allusion made to it, in the law of Zeno), which concerns on the one hand typical problems as the distance between buildings (prescribed for 12 or 10 feets), and on the other new ones, much more technical then even before, which show the reality of those times. We find there regulation of the construction of balconies ${ }^{28}-$ the space between them should be equal to 10 feet (fig. 14), they should be built of good masonry and access from the street to the balconies across exterior stairs was prohibited. Introduced is also the typology of windows ${ }^{29}$ (the panoramic one from witch one can hang on ( $\theta v \rho i \varsigma \pi \alpha \rho \alpha \kappa v \pi \tau ı \kappa \eta)$ and the light hole, which is a high level window, 6 feet above the floor ( $\varphi \omega \tau \alpha \gamma \omega \gamma$ ó $\varsigma$ ), the regulation of the view and light protection, ${ }^{30}$ as well as the arrangement of the shops along the main streets. ${ }^{31}$ Emperor Justinian decided in year 531 to extend this law to the whole Empire (C. 8.10.13). Justinian, himself, promulgated two novels concerning the view protection, which were complementary to Zeno's Law (Nov. 63 (538) and Nov. 165 (date unknown).

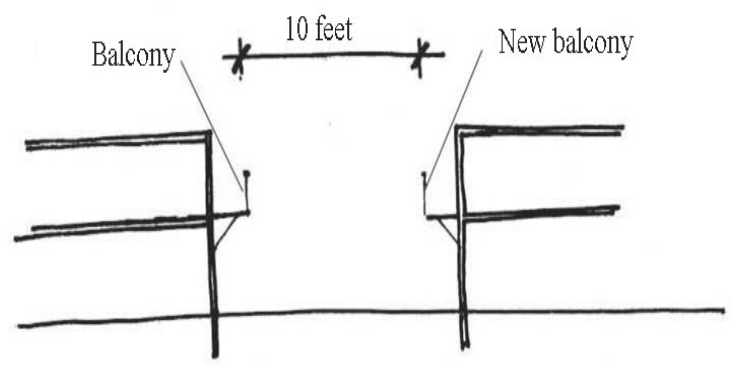

Fig. 14. Distance between balconies according to the constitution of Zeno.

\footnotetext{
27 SALIOU Catherine. Les lois des bâtiments: voisinage et habitat urbain dans l'empire romain. Recherches sur les rapports entre le droit et la construction privée, du siècle d'Auguste au siècle de Justinien. Beyrouth 1994, p. 283-4; CURSI Floriana. Modus Servitutis. Napoli 1999, p. 346-57.

28 C. 8.10 .12 .5

29 C. 8.10 .12 .2

30 C. $8.10 .12 .4-4 a$

31 C. $8.10 .12 .6-6 \mathrm{c}$
} 
Also later one, in 9th century we have imperial constitutions and compilations related to private dwellings, even if, obviously their were not any more in force in the Near East, but their show the century-long continuity of this kind of regulations. Leo VI the Philosopher (866-912, emperor form 886) enacted two Novels concerning private housing. Nov. 71 prescribes a minimal distance between two buildings in rural context (two arrowshots from the boundary of the neighboring land) and Nov. 113 establishes the distance of 10 feet between a balcony and the neighbouring building. Also in the Basilics (a digest of laws began by the Byzantine emperor Basilius in 867, and completed by his son Leo, the philosopher, in 880) their is 58th book dedicated to neighbourship and private building and in the title 11 of this book is repeated title 10th of Book 8th of the Codex of Justinian with addition of Nov. 63 and 165 of Justininan, and the Nov. 71 of Leo VI. ${ }^{32}$

As important in subject of private buildings, as imperial constitutions, if even not more, because of their regional character, are local sources from the Byzantine near East. First of them is the Liber Syro-Romanus ${ }^{33}$ - the legal compilation written originally in Greek (known to us from the translation into the sirian, arabic and aramaic) in the 5th century, probably in Beirut. It deals primarily with the law of family, slavery and inheritance and only with few problems of the private buildings - types of windows, division of construction and repair costs. ${ }^{34}$

The most important source in the matter of private buildings is Julian of Ascalon's Treatise ${ }^{35}$ written at the end of 5th or during the 6th century AD by an architect called Julian and preserved to us through the manuscript tradition, as making part of Eparchikon Biblion ${ }^{36}$ (collection of laws concerning trade and industry from 912) and Hexabiblos of Harmenopulos from Thessalonic (1345) and which text was reconstructed

\footnotetext{
SALIOU Catherine. The Byzantine House, p. 201.

33 SELB Walter. Zur Bedeutung des syrisch-römischen Rechtsbuches. München 1964. Text Liber syroromanus, FIRA II.

$34 \S 98$ about division of costs in case of use of already existed wall to the construction of new building (owner of new house had to pay $1 / 2$ of the costs) or in the case of repair of the stories of existing building (owner of every floor bears costs of repair of his floor and everyone participated in proportional way in costs of repair of ground floor).

$\$ 120$ Obligation to keep the distance of 2 cubits form the neighbour wall. Enumeration of three categories of windows: window wide 1 cubit, double window ( 2 cubits wide) and high ,ceiling” window, with different regulations of the distance between the buildings depending on their location on the ground flour or first flour.

35 SALIOU Catherine. Le traite d'urbanisme de Julien d'Ascalon, Paris 1996; SALIOU Catherine. Le traité de droit urbain de Julien d'Ascalon coutumier et codification. In: LEVI Edmond (eds.), La codification des lois dans l'Antiquité: actes du colloque de Strasbourg, 27-29 novembre 1997. De Boccard 2000, p. 293-313; SCHELTEMA Herman Jan. The nomoi of Julianus of Ascalon. In: Symbolae ad Ius et Historiam Antiquitatis Pertinentes Julio Christiano van Oven Dedicatae, Leiden 1946, p. 394-360; SALIOU Catherine. De la maison à la ville: le traité de Julien d'Ascalon. In: GALOR Katharina, WALISZEWSKI Tomasz (eds.), From Antioch to Alexandria. Recent studies in domescti architecture. Warszawa 2007, p. 169-178; HAKIM Besim S. Julian of Ascalon treatise of construction and design rules from sixth-century Palestine. In: Journal of the Society of Architectural Historians 60(1) (2001), p. 4-25.

36 NICOLE Jules. Le livre du Préfet ou l'édit de l'empereur Léone le Sage. Geneve 1893.
} 
by Caterin Saliou ${ }^{37}$. It is the longest and the most complex collection of rules concentrated exclusively on private buildings and their parts characteristic of the Near Eastern constructions - a courtyard, a flat roof used for many domestic activities, balconies, windows etc., where we can find a very detailed description of the regulations concerning construction, renovation and maintenance of the houses and their appurtenances.

This work is divided in parts on the basis of four elements:

fire (§3-15) - prescribes the distances between houses and different types of workshops (therms, bakery, klin, lime furnace)

air (\$16-39) concerns many different questions, like the distance between buildings and balconies, opening of windows and doors, replacement of structural elements (columns, pillars), the division of construction and renovation costs among owners of different floors, use of flat roofs and construction of superstructures on them and much more

water (§ 40-46) - regulates matters concerning water and water-installations like cisterns, canals and distance between them and neighbouring buildings

earth (§ 47-51) - concerning earthworks and planting also with distances prescribed between this kind of works and private buildings.

At the end there is a small paragraph related to the protection of view ( $\S$ 52-56) on the see, gardens and trees, public paintings and mountains.

According to the Julian of Ascalon's treaties, houses in the Palestine might be one, two, three o four stories buildings ( $\$ 33-35)$ organized around a central courtyard $(\S 24,38)$, with a flat roof $(\S 32)$. Their facades might be decorated with pilasters $(\S 23)$, columns or balconies $(\S 25)$. This picture agrees with our general knowledge about the domestic architecture in the Near East, based on archaeological remains.

Due to its local and technical features, the book of Julian is a very informative source for housing in Palestine during the Late Antiquity, and it complements the archaeological data ${ }^{38}$ in much more complex way then other sources we know, but generally thanks to all of these sources - both imperial and local one, we receive an exhaustive picture of the Near East domestic architecture of the Byzantine period in its juridical context.

37 SALIOU Catherine. Le traite d'urbanisme de Julien d'Ascalon, Paris 1996.

38 SALIOU Catherine. The Byzantine House, p. 201. 


\section{Bibliography}

AMELOTTI, Mario. L'epigrafe di Pergamo sugli astynomoi e il problema della recezione di leggi straniere nell'ordinamento giuridico romano. Studia et Documenta Historiae et Iuris, v. 24, p. 80$111,1958$.

BAGNALL, Roger S.; DEROW, Peter. The Hellenistic Period: Historical Sources in Translation. Malden 2004

BALTY, Janine. La Maison aux Consoles. In: BALTY, Janine (eds.). Actes du colloque Apamée de Syrie. Bilan des recherches archéologiques 1973-1979. Bruxelles 1984. p. 19-24.

BALTY, Jean-Charles. La maison urbaine en Syrie. In: DENTZER, Jean-Marie; ORTHMANN, Winfried (eds.). Archeologie et historie de la Syrie II, La Syrie de l'époque achéménide à l'avènement de l'Islam. Saarbrücker 1989. p. 407-22.

CURSI, Floriana. Modus Servitutis. Napoli, 1999

DUCHENE, Herve. La Stèle du Port. Fouilles du Port 1. Recherches sur une nouvelle inscription thasienne. Athens, 1992.

Dikaiomata: Auszüge aus alexandrinischen Gesetzen und Verordnungen in einem Papyrus des Philologischen Seminars der Universität Halle (Pap. Hal. 1) mit einem Anhang weiterer Papyri derselben Sammlung, Berlin 1913

FREZOULS, Edmond. A propos de l'architecture domestique a Palmyre. In: Ktema 1 (1976), p. $29-52$

GAWLIKOWSKI, Michał. Beyond the Colonnades: Domestic Architecture in Palmyra. In: GALOR, Katharina; WALISZEWSKI, Tomasz (eds.). From Antioch to Alexandria. Recent studies in domescti architecture. Warszawa 2007. p. 80-93.

HAKIM, Besim S. Julian of Ascalon treatise of construction and design rules from sixth-century Palestine. Journal of the Society of Architectural Historians, v. 60, n. 1, p. 4-25, 2001.

HIRSCHFELD, Yizhar. The Palestinian Dwelling in the Roman-Byzantine Period. Jerusalem 1995 MATTHA, Girgis. The demotic legal code of Hermopolis West. Kairo 1975

NICOLE, Jules. Le livre du Préfet ou l'édit de l'empereur Léone le Sage. Geneve 1893

SALIOU, Catherine. De la maison à la ville: le traité de Julien d'Ascalon. In: GALOR, Katharina, WALISZEWSKI, Tomasz (eds.). From Antioch to Alexandria. Recent studies in domescti architecture. Warszawa 2007, p. 169-178

SALIOU, Catherine. Le traite d'urbanisme de Julien d'Ascalon. Paris, 1996

SALIOU, Catherine. Le traité de droit urbain de Julien d'Ascalon coutumier et codification. In: LEVI, Edmond (eds.). La codification des lois dans l'Antiquité: actes du colloque de Strasbourg, 27-29 novembre 1997. De Boccard, 2000. p. 293-313 
SALIOU, Catherine. Les lois des bâtiments: voisinage et habitat urbain dans l'empire romain. Recherches sur les rapports entre le droit et la construction privée, du siècle d'Auguste au siècle de Justinien. Beyrouth 1994

SALIOU, Catherine. The Byzantine House (400-912): Rules and Representations. In: GRÜNBART Michael, KISLINGER Ewald, MUTHESIUS Anna, STATHAKOPOULOS Dionysios Ch. (ed.). Material Culture and Well-Being in Byzantium (400-1453), Wien 2007, p. 199-206

SCHELTEMA, Herman Jan. The nomoi of Julianus of Ascalon. In: Symbolae ad Ius et Historiam Antiquitatis Pertinentes Julio Christiano van Oven Dedicatae, Leiden 1946, p. 394-360

SEIGNE, Jacques. Habitat hellenistique et romain de Gerasa. In: CASTEL, Corinne; MAQDISI Mishal; VILLENEUVE, Francois (eds.). Les maisons dans la Syrie antique du III millénaire aux débuts de l'islam. Actes du Colloque International, Damas 27-30 juin 1992. Beyrouth 1997, p. 73-82

SELB, Walter. Zur Bedeutung des syrisch-römischen Rechtsbuches. München 1964

TATE, Georges. Asetto del villagio. In: La Civilta bizantina. Ogetti e messaggio. Architettura e ambiente di vita. Corso di studi 6, 1981. p. 75- 171

TATE, Georges. La maison rurale en Syrie du Nord. In: CASTEL, Corinne; MAQDISI, Mishal; VILLENEUVE, Francois (eds.). Les maisons dans la Syrie antique du III millénaire aux débuts de l'islam. Actes du Colloque International, Damas 27-30 juin 1992. Beyrouth 1997. p. 95-101

TCHALENKO, Georges. Villages antiques de la Syrie du Nord. Le massif du Belus a l'epoque romaine. Paris, 1953-58. 